\title{
Disrupting the Desert Scene: The Impact of Oil Discovery in Abdelrahman Munif's Cities of Salt
}

\author{
Mohammed Albalawi \\ Ministry of Education, Kent State University, Saudi Arabia
}

Copyright (C) 2015 by authors, all rights reserved. Authors agree that this article remains permanently open access under the terms of the Creative Commons Attribution License 4.0 International License

\begin{abstract}
The Arabic magnum opus Cities of Salt (1984) explores the struggle of Arabs in an unnamed Gulf emirate following the discovery of oil. The picture of Arabs living a harsh life in an oil-producing country may strike some people. Therefore, this paper attempts to establish a new perception by examining the novel and shows the far-reaching impact of oil discovery on the physical and human scene. Furthermore, this paper discusses the American-Arabs encounter displayed in Cities of Salt, which is an important one because it is a cultural confrontation rather than a political one. Because the novel is a quintet-almost 2500 pages spanning over seven decades, this paper looks at excerpts from the first volume that fit more appropriately this paper argument.
\end{abstract}

Keywords Oil Discovery, Arabic Literature, Desert, Cultural Confrontation, Arab, American

People of Wadi al-Uyoun, you will be among the richest and happiest of all mankind, as if God saw none but you!" Abdelrehman Munif, Cities of Salt 85

\section{Introduction}

Cities of Salt (1984) is highly significant in Arabic literature because - unlike many works where the events take place in underprivileged places-Munif's novel explores the struggle of people in a Gulf emirate following the discovery of oil. ${ }^{\mathrm{i}}$ Even though the emirate is unnamed, many critics believe that the reference is to Saudi Arabia. ${ }^{\text {ii }}$ However, this article argues that drama in the novel pertains to all oil-producing Arab nations that have failed to meet their people's needs. The perception of people living harsh lives in an oil-producing country may strike some people. Therefore, this article attempts to establish a new awareness by examining how Cities of Salt can eventually replace faulty information found in one's perception. Finally, this article discusses the American-Arabs encounter portrayed in Cities of Salt, which is an important one because it is a cultural confrontation rather than political one.

It is no surprise that many people equate Arabs with Sheikhs who have come to represent fabulous wealth, greed, indifference, and mores. This perception has been ingrained in American popular culture for many decades, even before the discovery of oil. ${ }^{\text {iii }}$ Not all Arab nations produce oil. ${ }^{\text {iv }}$ In fact, the majority of Arab nations are considered poor. But even in places where one expects people to live a privileged life, suffering exists, embedded in the poor's plight. Cities of Salt offers a medium through which readers can see how the author "brilliantly captures the traumatic changes undergone by ... [Arabs] in the last century."v What is unique about the story is that it has no main protagonists. Characters appear and disappear throughout the novel. The settings, however, are the central tools with which the author attempts to show the far-reaching impact of oil discovery on the physical and human scene. ${ }^{\text {vi }}$

\section{Wadi Al-Uyoun: The Place of Contentment}

The narrator begins the story by giving a vivid description of Wadi Al-Uyoun (The Oasis Valley), which is the central location of the first volume of Cities of Salt. Bedouins, who inhabit the Valley, appear to have lived the life of contentment. Even though the Valley is in a harsh desert, the palm trees and the pouring brooks seem to give it prominent standing not only among its inhabitants, but also among travelers. To show how the Valley is a marvel in the eyes people, the author writes:

Wadi al-Uyoun was a phenomenon, something of a miracle, unbelievable to those who saw it for the first time and unforgettable forever after. The wadi's name was repeated at all stages of a journey, in setting out and returning: "How much longer to Wadi al-Uyoun?" "If we make it to Wadi al-Uyoun, we", rest up for a few days before going on," and "Where are you, Wadi al-Uyoun, earthly paradise." (2) 
Through the lines above, the author paints an intense picture of how the Valley has captured people's admiration. While living in or traveling through desert is agonizing, the presence of the Valley seems to give the Bedouin and caravans a sense of respite. The author spends several pages describing the life, food, and conventions in the Valley. Years of abundance and years of drought come in the Valley. Even though the Valley suffers difficult times when the only food available are dry dates, milk, and stale bread, people are happy and peaceful and fortunate as they have been blessed with the life they have lived. Luca D'Acci notes, “happiness is influenced by intangible (but real) factors like love, health, friends, hobbies, social relations, political context, natural environment, ethical or intellectual wishes and aims, etc" (56). From the beginning, it is apparent that the author wants to reveal that despite hardship in the Valley, people find happiness because they socialize, help each other, and entertain themselves by dancing, telling stories, and talking.

After describing the Valley, the author introduces a bald Bedouin tribesman, Miteb Al-Hathal, who, along with his family, has a deep passion for the Valley. Miteb loves his life in the Valley. However, when the news that three foreign people are living in the Valley, Miteb gets worried and wonders, "What are they after?" (26). The appearance of those foreigners, who turn to be Americans, seems to baffle Miteb not because the Valley has never had foreign guests, but because they speak Arabic and have settled at the residence of another important tribesman, Ibn Rashed (26). While rumors say the three Americans have come looking for water, Miteb is cynical about their presence, which leads him to investigate the matter. Miteb believes that foreigners would not endure the heat of the desert and the scarcity of food unless they wanted something. He goes to Ibn Rashed's place to observe the three Americans. In order to show how mysterious the three Americans look in the eyes of the Valley Bedouin, the author writes:

They were busy all day. They went places no one dreamed of going. They collected unthinkable things. They had a piece of iron-no one knew what it was or what they did with it - and when they returned in the evening they brought with them bags of sand and pieces of rock...they placed wooden markers and iron poles everywhere they went, and wrote on them, and wrote things no one understood on the sheets of paper they carried with then everywhere. (30)

Through the above passage, the author conveys the Bedouin's worries. They have closely observed the actions and words of the foreigners. The Bedouin do not realize that the three Americans are geologists who have brought their equipment to search for oil. ${ }^{\text {vii }}$ Even though the author does not specify a date in his narration of the events, it is clear now that this story is set in late 1933, when the search for oil in Saudi Arabia began. ${ }^{\text {viii }}$ The three geologists need Bedouin because they need trackers who know the desert traverses very well. But Miteb does not know these facts. He is apprehensive, thinking the foreigners' presence would create a threat to his beloved Valley. The author writes that Miteb "sensed that something terrible was about to happen. He did not what it was and when it would happen" (31). It is apparent that Miteb is attached to the Valley. Donald Powell Cole notes that "The Bedouin [are] strongly linked to the livestock they [raise] and [take] care of and which [are] dependent on the Bedouin, who themselves [depend] on their animals for much of their own livelihood and sustenance" (238). Miteb does not want anything to create unrest to the life in the Valley.

Not only has the presence of the geologists disturbed Miteb, but Ibn Rashed's behavior since he received the guests has disturbed him, too. Ibn Rashed shows "lavish attention and hospitality in the most demonstrative way" (32). Ibn Rashed's generosity is not surprising because the Bedouin are very generous toward their guests. Peutz records that the word Bedouin is synonymous with generosity. ${ }^{\text {ix }}$ Miteb is embarrassed at Ibn Rashed's behavior because he has appeared weak and submissive. Consequently, Miteb criticizes Ibn Rashed: "Talk to them like a man. Treat them like men" (33). Perhaps if Ibn Rashed had been acting normally, Miteb would have been less worried. In Miteb's mind, Ibn Rashed's suspicious behavior seems to be driven by prior orders from the emir. ${ }^{\mathrm{x}}$

The author presents a binary world in the Valley through the eyes of Miteb and Ibn Rashed. While Ibn Rashed feels delighted because of the guests' openhandedness as they hand out coins of English and Arab gold to people for even the simplest tasks, Miteb demonstrates both concern and distrust. Ibn Rashed epitomizes the innocent Bedouin who has good intentions toward others. He believes that the three Americans have come to help the Valley's inhabitants find water. Miteb denounces that belief and marks: "if they find what they're after, none of us will be left alive" (43). Even though Ibn Rashed acts in accordance to the emir's commands, Miteb sees that the Valley's inhabitants have to put their welfare before anything else, even if it leads them to disobey the emir. Cole notes that the Bedouin "express high regard for their customary law and to praise it as more effective than state law" (251). In presenting the character of Miteb, the author attempts to portray the worries one has about elements that disrupt a serene home. These worries end when the disruptive elements disappear. The moment the geologists leave, life in the Valley recovers its normal beat. The foreigners become almost a memory in the minds of the Valley people except Miteb, who anticipates hearing news about them even after their departure.

\section{The Threat Strikes Back}

For months, the people of the Valley have lived peacefully. But unexpectedly, the foreigners return accompanied by others and some of the emir's men. Within days, the rhythm of life in the Valley has changed. Equipment is everywhere, a camp is set up, and wires and fences are erected. Miteb is in extreme apprehension. The narrator describes Miteb's 
reaction to the newly built camp: "shaking like a leaf and glancing...like a wolf" (68). Now, the people in the Valley confirm Miteb's suspicions. They watch the outsiders closely with fear and silence. However, when the machinery starts working, people become frightened, as they have never seen or heard such things. In order to show the terror that has inhabited the Valley, the narrator says:

the machine started to roar again, frightening everyone...the sound was accompanied by a blinding light. Within moments scores of small but brilliant suns began to blaze, filling the whole area with a light with no one could believe or stand. The men and boys retreated and looked at the lights again to make sure they still saw them, and looked at each other in terror. The animals who drew near retreated in fright; the camels fled, and the sheep stirred uneasily. (69)

Here, the author articulates an important passage to display a unique encounter between the Bedouin and Americans. Prior to the search for oil, the Bedouin's life in the Valley was shaped by three dominant elements: family, water, and livestock. Machines had very minimal or perhaps no influence. Apparently, the drilling for oil has terrified the Bedouin and startled the animals. Peter Theroux notes that "through the locals' eyes, we experience something like science fiction, which the locals can only read as apocalyptic, as unthinkable metal machines appear and bulldoze the oasis, which in time becomes an oil field." ${ }^{x i}$ The drilling appears enigmatic in the Bedouin's eyes. They observe helplessly. But Miteb, who has prophesized a danger in the Valley, asks the people to stay away from the machines: "Go back people of Wadi al-Uyoun! If you don't go back you'll get burned and there'll be nothing left of you" (69). This incident has left a vivid mark in the people's minds. For days, they have talked and asked many questions about what has happened while "their hearts were full of fear" (69).

The author uses an interesting approach to show the encounter between the Bedouin (Saudis/ Arabs) and the Americans. The Bedouin's questions have gone unanswered. Had the Americans explained their plan, the locals would have been less concerned. But the people in the Valley had no knowledge about the oil drilling until after it had started. Even after the machines' noise frightens everybody, the foreigners show indifference to others. The author writes, "These foreigners who strode around and shouted, raising their arms and behaving with unheard-of peculiarity, took no notice of the people around them or their astonishment" (69). It is an intense encounter that, as Theroux argues, "paints one of Arabic literature's most riveting scenes of tribal civics in action." xii

It is not only the search for oil that disrupts the desert scene: the foreigners' customs also manage to exploit both fear and resentment amid the Valley's inhabitants. In their recess, the American workers stretch out on their stomachs wearing nothing but short trousers. The scene of these semi-naked foreigners infuriates the Bedouin. Ibn Rashed tells the Americans that people would not accept men lying around like this, especially because women pass by the camp on their way to bring water from the brook. Ibn Rashed fails to sway the men as they continue their routine every day. Even though Ibn Rashed has defended the Americans, he shares a common dissatisfaction with the men's appearance. As a result, women stop bringing water and the disgruntled people send a delegation to the emir saying, "Your Excellency, we have no objection to their taking water from the brook, but we'll die before we let them take it over. Our womenfolk, Your Excellency, our honor, Your Excellency...If you want to solve the problem, solve it. And if you don't want to solve it, we will ourselves" (79). It appears that the Americans want to retain a sense of home in the desert. However, the image of men lying semi-naked violates the Bedouin' honor code, which is fundamental to their life. Lila Abu-Lughod states that the honor code is a significant and "powerful social ideology" in the Bedouin society (251).

Because the emir has not resolved the Bedouin's complaint, Miteb, Ibn Rashed, and others embark on a journey to meet him. The emir, who looks exultant and expectant, talks before the Bedouin speak: "People of Wadi al-Uyoun, you will be among the richest and happiest of all mankind, as if God saw none but you" (85). The emir explains to the Bedouin that under their feet lies "oceans of oil" (86). The emir knows what the Bedouin want before they talk. He realizes that people feel distraught about the events taking place in the Valley. His words are meant to offer a sense of reward for the people's patience. The Bedouin reject the emir's offer. Ibn Rashed bluntly responds, "money is not everything in the world. More important are honor, ethics and our traditions" (85). Ibn Rashed's words are important as they reveal what constructs the social life in the Valley. Despite their poverty, the Bedouin's words demonstrate how indifferent they are to any materialistic aspirations that the emir seeks. The emir uses his authority as a weapon of intimidation as he alerts the Bedouin not to obstruct the foreigners' work. His words to Miteb are direct and ominous: "I am speaking to you and to all others, and let him who is present convey it to him who is absent. We have only one, medicine for troublemakers: that [pointing to a sword on the wall]" (87). The intensely threatening tone of the emir is striking, as it declares the inferiority of Valley's people. In his eyes, the Bedouin's aspirations deserve no recognition from authority. While the Bedouin request to maintain their values and traditions, the rulers desire wealth at the expense of the Bedouin's social life.

For years, the Bedouin have supported the establishment of an Arab state and rejected the imposition of any foreign mandate. They have cooperated with Arab leaders since the closing of the Ottoman Empire. ${ }^{\text {xiii }}$ A question remains: why has the emir not considered the Bedouin's request? It seems reasonable that the foreigners could work while maintaining the ethical code in the Bedouin society. They understand that if their rulers got the wealth they desire, the Bedouin's life 
would be worse. Therefore, Ibn Rashed bluntly tells the Emir, "You are the government...you'll get what you want, maybe even tomorrow. After the Christians fetch the gold for you from under the ground you'll be even stronger" (87). The emir, however, prefers to have proximity with the foreigners rather than with their own people. If the Bedouin interfere in the government's work, they will be punished by death. It is an interesting take from the author to exhibit the oppression of the Bedouin. Furthermore, in the Bedouin's eyes, the Emir appears weak and clueless about the foreigners' real intent, which the Bedouin believe is something other than helping Arabs finding oil. Anouar Majid notes, "Saudis [the Bedouin] remain deeply suspicious of America's designs on their country." "xiv The Bedouin has made it very clear to their leader that they have been happy before the foreigners' arrival and that the drilling for oil would not be "for God" (87).

After the Bedouin has returned from the meeting with the emir, the Valley is filled with nothing but despair and fear. The narrator describes the situation in the Valley by stating that people believe "an accursed catastrophic end" awaits them all (94). The author utilizes a passionately descriptive language to portray the emotional distress that has inhabited the Valley. The Bedouin appear puzzled as they encounter this unprecedented event. They attentively observe the iron machines and the men who operate them. The children are mystified as they anxiously go to touch the machines. The Bedouin are baffled as they ponder what will happen to the Valley, but their wonder comes to end the moment the tractors begin destroying the land. With very intense language, the author describes the collapse of the Valley as witnessed by Miteb:

When the mad machines went into action he screamed in a harsh but painted voice: "I'm sorry, Wadi al-Uyoun...I'm sorry!" This was the final, insane, accursed proclamation that everything had come to an end...the tractors ... attacked the orchards like ravenous wolves, tearing up the trees and throwing them to the earth one after another, and leveled all the orchards between the brook and the fields. After destroying the first grove of trees, the tractors turned to the next with the same bestial voracity and uprooted them. The trees shook violently and groaned before falling, cried for help, wailed, panicked, called out in helpless pain and then fell entreatingly to the ground, as if trying to snuggle into the earth to grow and spring forth alive again. (106)

It is such an emotive description of the Valley's end. Desperately and helplessly, the Bedouin watch their beloved home get demolished. There is no doubt that cutting down trees lead not only to the loss of habitat for species but also to climate change. ${ }^{\mathrm{xv}}$ While the desert is very hot, the trees provide shade, offering protection from the blazing sun. For the Bedouin, it is very excruciating to see the Valley falling apart in front of their eyes. The author uses colorful and powerful language to show this horrendous event, including phrases like "like ravenous wolves," "with the same bestial voracity," "shook violently," and "groaned." The use of personification in the above passage is remarkable. The narrator assigns emotional qualities - crying, wailing, and panicking - to emphasize the emotional damage resulting from this dramatic event. Miteb's words "I'm sorry, Wadi al-Uyoun...I'm sorry!" are indeed an apology on the behalf of the Bedouin for not saving the Valley. Miteb is hurt. He cries silently and does not stop. People have not seen him shed a tear before. The author writes, "He did not say one word. He did not curse. Not a single sound or word escaped his lips; he shed his tears, unashamed and unafraid, but not proud either. He looked quietly through his tears at the whole wadi and shook his head" (107). It is apparent that the destruction of the Valley has traumatized the Bedouin as the image of the machines demolishing their homes haunts them. Judith Herman notes that the traumatic moment becomes fixed in the memory that breaks spontaneously into consciousness. ${ }^{x v i}$ The Bedouin look at the ruined Valley as if it were a hallucination, not believing what has happened to their home. Because of the destruction of the Valley, the Bedouin are forced to leave. Miteb is the first one to disappear and no one knows where he has gone. Soon, the others leave the Valley as well.

\section{The Displacement of the Bedouin}

The Bedouin find it very hard to leave a place they have always loved. However, they are destitute. The Valley Bedouin embark on a quest to find a place where they can live. They travel through the desert undergoing torment, illness, and even death. It is not only the Valley people that have left, as the demolition of other towns and villages has led many to depart. Harran is another important town that author introduces to show the changes that happened to the Bedouin. The destruction of houses leaves people in shock. While many Bedouin observe the changes silently, others engage in them. The ships arrive from various foreign lands bringing cargos. Ibn Rashed becomes in charge of hiring Bedouin to help with unloading cargoes from the ships. It is a new experience for the Bedouin, and the ships bring many goods that the Bedouin marvel at. The author writes, "Despite the arrival of more ships and the interest and curiosity they provoked, as well as the exhausting work they provided, depriving the men of any ability to rest or even talk, everyone was in low spirits by the time night fell. Their depression grew when the work ended and the sound of the sea grew louder..." (194). Even though the Bedouin chose to work with the foreigners, they appear bitter and clueless. They work hard with the foreigners, hoping they can find answers to how their life will be. Because they do not find answers by the end of the day, they feel despondent when the night comes.

The town of Harran holds a different yet interconnected tale of destruction and dispossession. While the houses and 
landmarks in the Valley and Harran obliterated, the people of Harran receive reimbursements for the destruction of their land, unlike the people of the Valley. However, the Bedouin - whether from the Valley or Harran - are lost in whirlpool of bewilderment and sorrow. For a long time, the people in Harran have survived by fishing and receiving assistance from voyagers who arrive via ships. Regarding the condition of the town, the narrator says, "Harran had little contact with the world, but it remained strange and volatile" (195). The presence of the many Americans and the ships that contain an abundance of cargo drive the people of Harran to curiosity as they seek to understand the changes their town underwent by working with the Americans. However, the Bedouin appear as joke in the eyes of the outsiders:

The Americans gazed at them [the Bedouin workers] with a neutral curiosity... but this neutrality turned to amazement when they saw the Arabs carrying the lumber and steel posts from one place to another, and then the amazement turned to hilarity as they pointed at the workers bumping into the crates and falling down. The loud peals of laughter and pointing fingers made the men nervous and bitter and they made more mistakes...

The workers trudged in a herd back to the area designated as theirs on the western side of the site. And in spite of the sun that bore down from the sky like a raging cataract, darkness enveloped their eyes and hearts. Their throats were parched and filled with a bitterness that gave everything that taste of colocynth. (106)

The Bedouin seem wretched as they experience the imbecilic manners of the foreigners. They feel acrimonious even though they are getting money for their work. The mocking smiles and sneers are difficult for the Bedouin workers to bear. Because the Bedouin are strongly linked to each other, the agony is intense. George Lipsky notes, "The members of tribal village are united not simply by common residence but by membership in a tribe."xvii The pain is strong because it inhabits the tribal life. The author presents a different but interesting portrayal of the Bedouin's encounter with Americans. It seems that the author wants to portray the Bedouin as slaves. The above passage can be read as pertaining not only to trauma-literature, but also to slave narratives. The Bedouin are slaves. The Americans are the Bedouin owners who have come to drive them out of their lands, force them to do menial labor, and treat them as ignorant, worthless, and unskilled buffoons. The Bedouin endure the humiliation but they are powerless. They choose to cope with this mistreating by sleeping. The author presents the Bedouin's vulnerability in an aesthetic way to reveal the harm that the discovery of oil has brought to the desert scene.

\section{When Two Cultures Meet}

Harran becomes two distinct towns: Arab Harran and American Harran. The Bedouin workers are building both towns under the supervision of American engineers. Wearing overalls on their bodies and white caps on their heads, the Arab workers become different creatures that the Bedouin have never encountered. While Arab Harran struggles to maintain their values and traditions, American Harran becomes bigger and more spacious, but more uniquely alien, and the Bedouin observe everything in bewilderment. However, it is the arrival of an enormous ship that astonishes everyone. As the ship nears the shore, the Bedouin hear voices, songs, and drums. The ship has brought hundreds of people. The sight of women is unforgettable to the Bedouin because the women are perfumed and uncovered except for a small piece of colored cloth. The women appear shining and laughing. The narrator describes the appearance of these women by saying, "Their faces, hands, breasts, bellies - everything, yes, everything glistened, danced, flew" (214). The Bedouin approach the ship, struggling to understand this drastic departure from their norms.

The presence of American women seems to affect the desert scene drastically, as this day is marked as the birthdate of Harran (215). Even though the Bedouin were saddened by the destruction of homes in Harran, the first memories of the frightening Americans are almost gone, with the image of the ship's arrival dominating their recent memory. Not only do the musical instruments brought in the ship surprise the Bedouin, but the actions of the new Americans also overwhelm them. The author writes, "The men stroked the women and then attacked suddenly for hugs and kisses, and carried the women around on their backs, and made them sit on their laps" (217). The kisses and hugs interrupt the Bedouin society, and the Bedouin men struggle with the sexual temptation. Anouar Majid notes, "American ships unloading semi-naked women to entertain their isolated male compatriots awaken in Arab men a disturbing desire, one they can neither resist nor accept."xviii Now, it is not only the search for oil that dominates the Bedouin society. The habits of the Americans that are offensive to the Bedouin seem to ignite feelings of distress and disorientation. Even though the Bedouin show signs of dissatisfaction with the Americans' behaviors through shouting and pointing exuberantly, the Americans continue to provoke the conservative Arabs through their indecent exposure. To display how the indecent scene has exploited the Bedouin's fear and confusion, the author describes:

No one could believe his eyes: it was indescribable. Words failed them; it could not be happening. Even the boys and small children, constantly laughing and making remarks in their high voices, eventually fell silent, utterly spellbound by what they saw...The men were mostly quiet now and slightly dizzy, feeling sharp pains throbbing in certain parts of their bodies. Some cried out, and most of them wished that they had never come to see what was transpiring 


\section{before them. (217)}

This sudden encounter creates a new class system in which the Bedouin are confused. If we read this unprecedented event the Bedouin are experiencing in a political context, it is cultural imperialism. Edward Said notes, "Imperialism not only is a relationship of domination but also is committed to a specific ideology of expansion" (186). It is apparent that the Americans seek to extend their culture outside of their land, forcing the Arabs to accept it. The Arabs are truly shocked. Even though the Americans see how their behaviors have disturbed the Arabs, they continue their obscene display, especially after the relationship between the Americans and the Emir has been strengthened through their visits during the first weeks. These visits invite a closer inspection of the drastic difference between two cultures.

The emir and his close companions are the only ones allowed to set foot at the American compound, which immediately shows a sign of distrust. When the emir visits the compound, he is thrilled with everything he sees - the swimming pools, the recreation club, and the offices. $\mathrm{He}$ even asks to inspect one of the houses. The emir gazes in awe at the constructions, as he has never seen such things, but gazes more astoundingly at the sight of the naked women. Moreover, the emir takes up the Americans' offer for a boat ride, even though he has never sailed before. The emir trusts them. The visit of the Americans to the Emir's residence is an interesting one. For days, the emir has made preparations in the honor of the Americans. The author writes, "[the emir] and his men did everything in their power to make the party magnificent and the event memorable" (280-281). The Arabs' generous hospitality is a prominent feature of their culture, often considered the most outstanding feature of Arab customs. ${ }^{\text {xix }}$ To the emir and his men, the invitation is not a matter of social liability but rather of honor. The invitation is also considered a sacred duty. The reception takes place in a huge tent erected in the Americans' honor. The emir has arranged a camel race, an event that surprises the guests who thought camels are slow, used only as pack animals. When they see how fast the camels run, they take photographs, applaud, and seek to approach them when the race is over. The camel race is merely one part of the evening's entertainment. A few falcons are brought and shown to the guests, followed by a battle in the air when the falcons are dispatched after pigeons are set loose. The expression on the Americans' face shows astonishment and fear, as they have not encountered such a display before. The dinner the Arabs have prepared is indicative of the generous hospitality in the Arab culture. Not only do they place a camel's head among the dishes, but also they killed one sheep for each guest-a gesture exhibiting extreme hospitality and profound respect. After the dinner, the guests are entertained with a sword dance that the Arabs perform.

Nowhere in this encounter is an outside/insider dynamic exhibited. Both the Americans and the Arabs exchange visits to understand each other culture. This is the first instance in the novel where the author brings together the peoples of two very distinct geographies, languages, and customs. The Arabs' visit was short, and simple food was given. There was no entertainment. Simply, the visit's purpose was to tour the compound, and information about the constructions that astonished the guests was not given. If analyzed closely, one can say that not only did the Americans distrust their guests, but also they regarded them as people unworthy of learning. Contrastingly, the Arabs' lavish hospitality becomes apparent in the American's visit. William Young notes "Hospitality is a ubiquitous component of life in the Arab societies... [and] its importance for social relations has been well documented." ${ }^{x x}$ The American guests were greeted warmly, fed well, and entertained pleasantly. Because generous hospitality is highly valued as it contributes to the host's social reputation, not only did the Arabs provide food and entertainment, but they also taught their guests the sword dance. The question of women in both encounters is interesting. While the American women have appeared semi-naked in the Arabs' presence, the Arab women have had no contact with the American male guests. Arab women play no significant part when hospitality is offered to men.

The Americans' visits to the Bedouins' places have not stopped. Now, however, the Americans begin interacting with the locals. Perhaps they seek to understand the culture in an attempt to assimilate in their new home. Whenever the Arabs see Americans roaming around their houses, they invite them in for a cup of coffee or a glass of tea. What amazes the Bedouin about these interactions is not that the Americans scrutinize their hosts' faces or desire to touch the objects around them, but that the books that the Americans have brought with them contain information that is familiar to them - names of places, tribes, migration of birds, wind, and seasons for rainy weather. Not only do these books inspire bewilderment, but they inspire panic among the Bedouin as well. To each visit, the Americans bring books of different color and size, leading old men to believe their guests seek to harm their town. They declare, "They are magical books, and each of those men has a jinn of his own. Those Americans are trying out book after book to gain control Harran and its people" (286). ${ }^{\mathrm{xxi}}$ This conviction is strongly believed after one of the Bedouin's sons gets a fever the day after the Americans visited their house. The Bedouin believe that the jinn has infiltrated that Bedouin's house. .xii

Karl Scheibe and Theodore Sarbin note that people may acquire their superstitions from "direct verbal communication" becoming standard beliefs, and that these beliefs stand until replaced by a better belief (150-151). The Bedouin think the Americans practice witchcraft using these books. However, their conviction is deemed wrong when the Americans explained the nature of the books - geography, history, anthropology, and mores. Now, knowing the books contain neither witchcraft nor blasphemy, the Bedouin exhibit new worry and surprise. The author explains these fears: "They said that they had come to help the people and to search for water, that there was gold underneath the sands 
and that they would extract it and distribute to the people among the people, but what did any of that have to do with their books..." (287). The approach the author employs here to expose the Bedouin's worries is an interesting one. While the Bedouin opens their homes and culture to the outsiders, they feel suspicious toward any behavior the guests disclose. Adding to the Bedouin's doubts is the appearance of an old theologian who has come to study the Bedouin's religious beliefs and the evolution of the Islam religion. When he asks the Bedouin if they have practiced any other religious beliefs or if they have heard about others who practiced paganism, the Bedouin are frightened, thinking the theologian has appeared to turn the people away from Islam. The demolition of the towns, the appearance of the semi-naked women, the visits of explorations, the carrying of assorted books, and the emergence of the theologian exploit a seemingly endless supply of uncertainties and concerns, making the Bedouin suspect that their land is culturally and religiously threatened.

\section{How the Bedouin Receive Technology}

One of the arresting themes in Cities of Salt is that of knowledge-versus-ignorance, which appears primarily when technology is introduced in the Bedouin's society. With expressive language, the author describes how the emir and the Bedouin have received the radio. From one of the ships that arrive in Harran, a man brings a machine that the Bedouin have never seen. After he turns the knobs on the machine, sharp voices emerge. Regarding the Bedouin's reactions, the author writes, "Everyone present started violently, and a number of men retreated a few steps, and one man hid behind some others" (433). To the Bedouin, the music, the news, and the programs to which they are listening when the radio stations are being changed invite feelings of anxiety and fear. They are experiencing something new, something of mystic. The news of this marvelous gadget spreads, creating mystery among the people of Harran. The author describes the effect of the emergence of radio by writing, "Everyone began to talk about 'the new wonder,' and three or four of the men said that they heard a voice, during the day, which seemed to fall from the sky or spring from the earth. One of them said that one day he had heard a voice calling him, but when he turned around there was no one there" (436-437).

Here, the author portrays how the Bedouin's have perceived technology. The search for understanding of the device is met by the emir's failure to explain, causing the Bedouin's frustration. The Bedouin do not deride modernization, but rather pursue to understand the drastic shift in their culture. They seek answers from the emir, but all they hear- "something people had never heard of before"; "seeing it is nothing to hearing it"-which intensifies the mystery (437). The emir is attracted to technology, however, and does not care about the Bedouin's curiosity to understand it. The narrator shows how the emir is fascinated by the gadget by saying, "The emir was profoundly agitated the whole afternoon. He did not sleep and did not leave his tent, and his eyes never left his new gadget" (437). While the emir is impressed, the Bedouins exhibit fears. Anouar Majid records that as Arabs "begin denouncing this new cultural imperialism, the emir is increasingly seduced by Western gadgetry, including the radio and telephone, which strengthens the Arab leaders' connection with remote centers of power." "xiii Because the emir is less worried about the people's disquiets, the Bedouin are more susceptible to fears of losing their culture. While the Bedouin pursue understanding in their attempt to adapt to the changes in their life, they are afraid these gadgets are merely tools that the outsiders can use to control their existence. Afif Tannous notes "This strong national desire for the amalgamation of the tribe with the rest of the nation is enhanced by the fear of outside political interference" (6). The Radio gives the emir a sense of dominance. The emir does not exhibit any affectionate behavior toward his people, but rather feels superior to them. The Bedouin learn eventually about the radio from a traveler who has seen them before in his travels.

\section{When the Cultural Segregation Begins}

After the dismissal of many Bedouin workers from the oil company, the Americans feel unsafe. They ask the emir to provide guard units for the installations so trouble can be avoided. The appointment of guards initiates not only a cultural separation of the Bedouin from the Americans, but also a benefit segregation, which in time leads to frustration. To show how the Bedouin feel about this segregation, the author writes:
They felt afraid, but still dared to say things they would never have said had they not been so consumed with sorrow and anger. Why did they have to live like this, while Americans lived so differently? Why were they barred from going near an American house, even from looking at the swimming pool or standing fro a moment in the shade of one of their trees? Why did the Americans shout at them, telling them to move, to leave the place immediately, expelling them like dogs?

In this passage, the author articulates how the Bedouin are being dominated. First, the Bedouin are no longer allowed to approach the American's compound, which serves as a symbol of the American presence on the Arabs' land. This desire the Americans have to stop the Bedouin from approaching them indicates a desire for power over the Bedouin. Second, the Bedouin feel the subjugation after signpost warnings have been erected against loitering or going near most places. Even barbed wire has been put in the sea to keep the Bedouin at distance. Third, on a more personal level, people in Harran observe a new kind of power-the power to control and dominate another group. 
Using resources such as wealth, status, size, and weapons, the emir controls the Bedouin, who have come to realize that the emir is taking the Americans' side rather than theirs. They ask: "And the emir, was he their emir, there to defend and protect them, or was he the Americans' emir? He had been a different man when he fits came to Harran" (595). Not only does the author aim to exemplify how the Arab rulers have failed to meet their people's needs, but he demonstrates how the Arab rulers have changed as a result of the arrival of technology. Marion Young delineates a major aspect of oppression and powerlessness as the control one group has over one's own or another's actions (56). The Bedouin are powerless in the sense that they must follow the emir's orders without having the right to fight them. With the exhibition of the beginning of oppression, the author ends the first volume of Cities of Salt. However, the story continues as the author extends the various shortcomings and obstacles in the people's encounter with their regime.

\section{Conclusions}

As noted earlier, the suffering of people living in an oil-producing nation may be striking. This article has endeavored to find different insights by investigating themes from the first volume of Munif's Cities of Salt and shows the impact of oil discovery on the human scene, the American-Arabs cultural encounter, and the gradual transformation of the Bedouin's life from simplicity to complexity. ${ }^{\text {xxiv }}$ The Bedouin, who have been promised a prosperous life by the modern government, are deceived. Not only have the Bedouin tribes not maintained their authority in their lands, but they also have not been given recognition. However, neither the story nor the people's concerns end. In the remaining four volumes, the author continues dramatizing subsequent events that occur during several decades and explores how the oil discovery has rapidly caused wide-ranging transformations in the traditional social composition of Arab societies. The fast accumulation of oil revenues and the flow of wealth create an aggressive capitalist structure in the country in which the aspiration for progress and welfare fails.

\section{REFERENCES}

[1] Abu-Lughod, Lila. "Honor and the Sentiments of Loss in a Bedouin Society." American Ethnologist 12.2 (1985):
245-61.

[2] Burt, Daniel S. The Novel 100: A Ranking of the Greatest Novels of All Time. New York: Facts on File, 2004.

[3] Chatty, Dawn. "The Bedouin in Contemporary Syria: The Persistence of Tribal Authority and Control." The Middle East Journal 64.1 (2010): 29-49.

[4] Cole, Donald Powell. "Where Have the Bedouin Gone?" Anthropological Quarterly 76.2 (2003): 235-67.

[5] D'Acci, Luca. "Measuring Well-Being and Progress." Social Indicators Research 104.1 (2011): 47-65.

[6] Deforestation Facts, Deforestation Information, Effects of Deforestation - National Geographic." National Geographic. N.p., n.d. Web. 11 Feb. 2015.

[7] Ghazal, Rym. "Honour, Pride, Generosity: What It Means to Be Bedouin | The National." Honour, Pride, Generosity: What It Means to Be Bedouin | The National. The National, 3 Apr. 2012.

[8] Herman, Judith. Trauma and Recovery. New York: Basic, 1997

[9] Kay, Shirley. The Bedouin. New York: Crane, Russak, 1978.

[10] Lipsky, George A. Saudi Arabia, Its People, Its Society, Its Culture. New Haven: HRAF, 1959.

[11] Majid, Anouar. "The Failure of Postcolonial Theory After 9/11." The Chronicle Review. The Chronicle of Higher Education, 1 Nov. 2002.

[12] Munif, Abdulrahman., and Peter Theroux. Cities of Salt. New York: Vintage, 1989. Print.

[13] Said, Edward W. Culture and Imperialism. New York: Knopf, 1993. Print.

[14] "Saudi Aramco World: The Search Began In 1933. AramcoWorld, Feb. 1963.

[15] Scheibe, Karl E., and Theodore R. Sarbin. "Towards A Theoretical Conceptualisation Of Superstition." The British Journal for the Philosophy of Science XVI.62 (1965): 143-58.

[16] Shaheen, Jack Reel Bad Arabs: How Hollywood Vilifies a People." The Annals of the American Academy of Political and Social Science 588.1 (2003): 171-93.

[17] Tannous, Afif. "The Arab Tribal Community in a Nationalist State." Middle East Journal 1.1 (1947): 5-17. Print

[18] Theroux, Peter. "Abdelrahman Munif and the Uses of Oil." RSS. Words Without Borders, 2012.

[19] Young, William. "Arab Hospitality as a Rite of Incorporation." Anthropo 102,.1 (2007): 47-69. 


\section{Notes}

\footnotetext{
${ }^{i}$ Abdelrehman Munif is one of the few Arabic writers to have gained recognition in the English-speaking world. His magnum opus, Cities of Salt, is generally agreed to be his outstanding achievement. In his book, The Novel 100: A Ranking of Greatest Novels All Time, Daniel S. Burt lists Cities of Salt as no. 71. Burt who was for nine years a dean at Wesleyan University, where he has also taught literature courses since 1989.

ii Though no specific dates are given in the novel itself, parallelism between events in the novel and actual historical events happened in Saudi Arabia convey that the plot of volume one spans the period from the beginning of World War I to the early 1950's.

iii Shaheen's documentation of the representations of Arabs in media shows clearly the tendency in Hollywood to portray wealthy Arabs (Sheikhs) in very demeaning ways, for example, as people who get rich at the expense of Americans. See, Shaheen, "Reel Bad Arabs: How Hollywood Vilifies a People," 180-183.

iv Out of the twenty-two, there are only seven countries that produce oil in the Arab world: Saudi Arabia, being the largest, Kuwait, Iraq, Libya, Algeria, Syria.

v Majid, Anouar. "The Failure of Postcolonial Theory After 9/11." The Chronicle Review. The Chronicle of Higher Education, 1 Nov. 2002. Web. 21 Feb. 2015 .

vi In Arabic, Munif's work is a quintet—some 2,500 pages in length covering seven decades. Cities of Salt is the name of the quintet that includes The Labyrinth, The Trench, Variations on Night and Day, The Rootless, and The Desert of Darkness. In English, the novel is a trilogy: Cities of Salt (instead of The Labyrinth), The Trench, and Variations on Night and Day. This article looks themes from the first volume that fit more appropriately with this project's main arguments.

vii After oil was discovered in Bahrain in 1932, companies sent geologists for oil exploration in the Persian Gulf area. In May 1933, the California Arabian Standard Oil Company obtained a concession to search for oil, and develop production, in Saudi Arabia. See "Saudi Aramco World: The Search Began In 1933." Saudi Aramco World: The Search Began In 1933. AramcoWorld, Feb. 1963. Web. 25 Feb. 2015.). viii Ibid

${ }^{\text {ix }}$ Ghazal, Rym. "Honour, Pride, Generosity: What It Means to Be Bedouin | The National." Honour, Pride, Generosity: What It Means to Be Bedouin | The National. The National, 3 Apr. 2012. Web. 09 Mar. 2015.

${ }^{x}$ Emir (the prince or commander) refers to a leader of people. The text does not give more information about the identity of the emir. However, since the context talks about the discovery of oil, emir refers to the ruler of the eastern region of Saudi Arabia in the 1930s.

xi Theroux, Peter. "Abdelrahman Munif and the Uses of Oil." RSS. Words Without Borders, 2012. Web. 10 Mar. 2015.

xii Ibid

xiii Chatty, Dawn. "The Bedouin in Contemporary Syria: The Persistence of Tribal Authority and Control." The Middle East Journal 64.1 (2010): $32-34$.

xiv See Majid

xv "Deforestation Facts, Deforestation Information, Effects of Deforestation - National Geographic." National Geographic.

vvi Herman, Judith. Trauma and Recovery. New York: Basic, 1997. (37)

xvii See Lipsky 61-64.

xviii See Majid

xix Tannous, Afif. "The Arab Tribal Community in a Nationalist State." 11

xx See Young, William. "Arab Hospitality as a Rite of Incorporation." 47

xxi Jinn is a supernatural creature in Islamic mythology.

xxii For a long time, the Bedouin had no idea of the cause of their own or their children's illness, and no scientific way of remedying them. They believe in the 'evil eye' See Kay, Shirley. The Bedouin. New York: Crane, Russak, 1978. 29

xxiii See Majid

xxiv In his interesting article, "Where Have the Bedouin Gone?" Donald Powell Cole records that after the oil discovery, the majority of the Bedouin were all but gone. They became taxi drivers, traders, or worked for oil companies. The modernity has replaced nomad camp and tribe, or tradition. See Cole, Donald Powell. "Where Have the Bedouin Gone?" Anthropological Quarterly 76.2 (2003): 235-67.
} 